J. Clin. Chem. Clin. Biochem.

Vol. 15, 1977, pp. 715-718

\title{
A New Method for Determination of Inorganic Phosphorus in Serum without Deproteinization
}

\author{
By Mahmoud Mohamed El-Merzabani, Abdelbaset Anwer-El-Aaser and Nadia Iskandar Zakhary \\ Cancer Chemotherapy and Cell Chemistry Units, Cancer Institute, Cairo University, Cairo-Egypt
}

(Received July 6, 1976/January 26, 1977)

Summary: A simple method was developed for the determination of inorganic phosphorus in serum without deproteinization. The method is based on the use of formic acid as protein solubilizer and glycerol as stabilizer for the assay system. The optimal conditions for colour development were determined. The results obtained with the new method correlate well with those obtained after deproteinization of serum with trichloroacetic acid. The present method could be fully mechanized, and its application to the determination of serum phosphatases is discussed.

\section{Eine neue Methode zur Bestimmung von anorganischem Phosphat im Serum ohne Enteiweißung}

Zusammenfassung: Eine einfache Methode zur Bestimmung von anorganischem Phosphat im Serum ohne Enteiweißung wurde entwickelt. Die Methode benutzt Ameisensäure zur Lösung der Proteine und Glycerin zur Stabilisierung des Bestimmungssystems. Die optimalen Bedingungen für die Farbentwicklung wurden bestimmt. Die mit der neuen Methode erhaltenen Ergebnisse korrelieren gut mit den nach Enteiweißung des Serums mit Trichloressigsäure erhaltenen. Die Methode könnte voll mechanisiert werden. Ihre Verwendung zur Bestimmung der Phosphatasen im Serum wird diskutiert.

\section{Introduction}

Inorganic phosphorus, present in serum as phosphate, forms a phosphomolybdate complex with molybdic acid. The latter can be easily reduced to a blue colour, which can be measured colorimetrically. This reaction is applied widely in clinical chemistry $(1,2)$.

In our preliminary investigations to determine serum phosphorus without deproteinization, it had been found that formic acid, together with glycerol, could solubilize serum proteins even in the presence of ammonium molybdate. When glycerol was omitted serum proteins were reprecipitated after the addition of ammonium molybdate. Ëthylene and propylene glycols, in higher concentration, gave the same effect as glycerol in the presence of formic acid.

Therefore it was of interest to fully investigate the optimal conditions for the determination of serum phosphorus without deproteinization using formic acid as protein solubilizer and glycerol as stabilizing agent for the assay system.

\section{Material and Methods}

Reagents required for the established method mentioned in table 1, are:

\section{Protein solubilizer}

Use pure formic acid $1220 \mathrm{~g} / 1$ (density 1.22 , Prolabo)

\section{Stabilizer}

Mix $300 \mathrm{ml}$ glycerol (density 1.263, Prolabo) with $700 \mathrm{ml}$ distilled water, this will give a concentration of $378 \mathrm{~g} / 1$. Keep in closed brown container.

\section{Ammonium molybdate}

Dissolve $10 \mathrm{~g}$ ammonium molybdate (BDH) in one litre of distilled water. The solution is stable at room temperature.

4. Reagent mixture for use (formic acid/glycerol/molybdate) Mix solution 1, 2 and 3 in a ratio of $200 \mathrm{ml}+200 \mathrm{ml}+100 \mathrm{ml}$ respectively. Keep in closed brown container. Solution is stable for up to thruee weeks.

\section{Reducing agent}

Use freshly prepared stannous chloride (BDH), $1.5 \mathrm{~g} / 1$ in $1 \mathrm{~mol} / \mathrm{l}$ hydrochloric acid.

\section{Standard phosphorus}

Dissolve $0.0878 \mathrm{~g}$ potassium dihydrogen phosphate (BDH) in one litre distilled water. Add few drops of chloroform and keep at $4^{\circ} \mathrm{C}$. This solution contains $20 \mathrm{mg} / \mathrm{l}$ phosphorus $\left(\mathrm{P}_{\mathrm{i}}\right)$.

\section{Phosphorus determinations}

Phosphorus was determined in serum without deproteinization using formic acid and glycerol according to the optimal conditions outlined in Table 1. For comparison, parallel determinations were carried out after deproteinization with trichloroacetic acid according to Kuttner \& Lichtenstein (3): $0.2 \mathrm{ml}$ serum, in final 
Tab. 1. Standard formic acid-glycerol procedure:

\begin{tabular}{|c|c|c|c|c|}
\hline Reagent & Test & $\begin{array}{l}\text { Test } \\
\text { blank }\end{array}$ & Standard & $\begin{array}{l}\text { Standard } \\
\text { blank }\end{array}$ \\
\hline Distilled water [ml] & 0.4 & 0.9 & - & 0.5 \\
\hline Serum [ml] & 0.1 & 0.1 & - & - \\
\hline $\begin{array}{l}\text { Standard phosphorus } \\
\text { [ml] }\end{array}$ & - & - & 0.5 & - \\
\hline Solution $4[\mathrm{ml}]$ & $\begin{array}{l}2.5 \\
\text { Mix, then }\end{array}$ & $\begin{array}{l}2.5 \\
\text { add, }\end{array}$ & 2.5 & 2.5 \\
\hline Solution 5 [ml] & $\begin{array}{l}0.5 \\
\text { Mix, stand } \\
720 \mathrm{~nm} \text { ag } \\
\text { cuvette. }\end{array}$ & $\begin{array}{l}\text { d for } 30 \\
\text { gainst th }\end{array}$ & $\begin{array}{l}0.5 \\
\text { nin, read at } \\
\text { blank, usin }\end{array}$ & $\begin{array}{l}0.5 \\
640- \\
\mathrm{gg} 1 \mathrm{~cm}\end{array}$ \\
\hline
\end{tabular}

volume of one $\mathrm{ml}$, was treated with $5 \mathrm{ml}$ of $160 \mathrm{~g} / 1$ trichloroacetic acid; after centrifugation a $3 \mathrm{ml}$ aliquot (equivalent to $0.1 \mathrm{ml}$ serum) was mixed with $0.5 \mathrm{ml}$ of $10 \mathrm{~g} / 1$ ammonium molybdate, followed by $0.5 \mathrm{ml} 1.5 \mathrm{~g} / \mathrm{l}$ stannous chloride. After standing for 30 minutes, the colour was measured at $640 \mathrm{~nm}$, using a Unicam SP 500 and a $1 \mathrm{~cm}$ cuvette.

Calculation

Phosphorus, mg/dl serum:

$\frac{\mathrm{A}_{640} \text { test }}{\mathrm{A}_{640} \text { standard }} \times 0.01\left(\mathrm{mg} \mathrm{P}_{\mathrm{i}}\right) \times \frac{100 \text { (per hundred) }}{0.1 \text { (ml of serum used) }}$

Phosphorus, mmol/1 serum:

$\mathrm{mg} / \mathrm{dl} \times 0,01292$

\section{Results}

\section{Establishment of optimal conditions}

\section{Effect of formic acid and glycerol}

As shown in table 2, the assay of $2.85 \mathrm{mg} / \mathrm{l}$ phosphorus in the presence of a constant concentration of formic acid $(348 \mathrm{~g} / \mathrm{l})$ and different concentrations of glycerol (88 to $126 \mathrm{~g} / \mathrm{l}$ in the final assay mixture) showed an optimal optical density of 1.05 at $640 \mathrm{~nm}$, irrespective of the presence or absence of serum. This value correlates well

Tab. 2. Effect of different concentrations of formic acid and glycerol.

\begin{tabular}{|c|c|c|c|c|}
\hline $\begin{array}{l}\text { Formic acid } \\
{[\mathrm{g} / \mathrm{l}]}\end{array}$ & $\begin{array}{l}\text { Glycerol } \\
{[\mathrm{g} / 1]^{(\mathrm{a})}}\end{array}$ & $2.85 \mathrm{mg} / \mathrm{l} \mathrm{P}_{\mathrm{i}}$ & $\begin{array}{l}2.85 \mathrm{mg} / 1 \mathrm{P}_{\mathrm{i}} \\
+\operatorname{serum}^{(\mathrm{b})}\end{array}$ & $\begin{array}{l}\text { Recovery } \\
\%\end{array}$ \\
\hline $\begin{array}{l}348 \\
348 \\
348 \\
348 \\
348\end{array}$ & $\begin{array}{r}88 \\
107 \\
126 \\
145 \\
164\end{array}$ & $\begin{array}{l}1.08 \\
1.08 \\
1.05 \\
0.87 \\
0.54\end{array}$ & $\begin{array}{l}1.02 \\
1.02 \\
1.05 \\
0.99 \\
0.66\end{array}$ & $\begin{array}{r}94.4 \\
94.4 \\
100.0\end{array}$ \\
\hline $\begin{array}{l}170 \\
244 \\
317 \\
348\end{array}$ & $\begin{array}{l}126 \\
126 \\
126 \\
126\end{array}$ & $\begin{array}{l}1.05 \\
1.00 \\
1.00 \\
1.05\end{array}$ & $\begin{array}{l}1.02 \\
1.02 \\
1.05 \\
1.05\end{array}$ & $\begin{array}{r}97.1 \\
102.0 \\
105.0 \\
100.0\end{array}$ \\
\hline \multicolumn{2}{|c|}{$\begin{array}{l}\text { Trichloroacetic acid } \\
\text { method }\end{array}$} & 1.10 & 1.10 & 100.0 \\
\hline
\end{tabular}

- Data represented as $\mathbf{A}_{640} \mathrm{~nm}$

- Ammonium molybdate concentration in the assay mix̄ture was $1.43 \mathrm{~g} / 1$.

(a) Formic acid and glycerol as final concentration $(g / l)$ in the assay medium.

(b) Serum blank was subtracted. with that obtained after deproteinization with trichloroacetic acid. However, colour development was abolished when glycerol was used at concentration of more than $126 \mathrm{~g} / \mathrm{l}$ in the absence or presence of serum.

On the other hand, when glycerol was used at a concentration of $126 \mathrm{~g} / \mathrm{l}$, and the concentration of formic acid was increased from 170 to $348 \mathrm{~g} / 1$, colour development, was not affected and the results correlated well with those obtained with trichloroacetic acid.

Accordingly, $348 \mathrm{~g} / \mathrm{l}$ formic acid and $107 \mathrm{~g} / \mathrm{l}$ glycerol as a final concentration in the assay mixture were selected as the optimal concentrations for the present work.

\section{Effect of ammonium molybdate}

As shown in table 3, the amount of ammonium molybdate required for optimal colour development increases with increasing glycerol concentration. In the presence of serum and $101 \mathrm{~g} / 1$ glycerol, ammonium molybdate in a concentration of $1.12 \mathrm{~g} / 1$ is optimal for colour development. This concentration is identical to that required after deproteinization with trichloroacetic acid. In the absence of serum, and at the same concentration of glycerol, a minimum concentration of $1.68 \mathrm{~g} / \mathrm{l}$ is required for optimal colour development. However the concentration used in the method outlined in Table 1 was $1.43 \mathrm{~g} / 1$.

Tab. 3. Effect of different concentrations of ammonium molybdate and glycerol on phosphorus determination in the presence of $348 \mathrm{~g} / 1$ formic acid.

\begin{tabular}{lrrrrrrr}
\hline Assay medium & Glycerol & \multicolumn{5}{c}{ Ammonium molybdate [g/l] } \\
& {$[\mathrm{g} / \mathrm{l}]$} & 0.56 & 1.12 & 1.68 & 2.24 & 2.80 \\
& & & & & & \\
& 63 & 0.48 & 1.14 & 1.11 & 1.14 & 1.14 \\
Glycerol & 101 & 0.06 & 0.90 & 1.11 & 1.14 & 1.14 \\
$+2.85 \mathrm{mg} / 1 \mathrm{P}_{\mathrm{i}}$ & 139 & 0.03 & 0.54 & 0.99 & 1.14 & 1.08 \\
& 176 & 0.03 & 0.06 & 0.66 & 1.14 & 1.11 \\
& 63 & 0.87 & 1.05 & 1.29 & $\mathrm{ppt}$ & $\mathrm{ppt}$ \\
& 101 & 0.51 & 1.11 & 1.14 & 1.15 & 1.13 \\
Glycerol & 139 & 0.09 & 1.17 & 1.11 & 1.11 & 1.11 \\
$+2.85 \mathrm{mg} / 1 \mathrm{P}_{\mathrm{i}}$ & 176 & 0.06 & 0.60 & 1.14 & 1.17 & 1.08 \\
+ serum & & 0.30 & 1.05 & 1.05 & 1.05 & 1.05 \\
& & & & & & \\
$\begin{array}{l}\text { Trichloroacetic } \\
\text { acid }+2.85 \mathrm{mg} / 1 \mathrm{P}_{\mathrm{i}}\end{array}$ & & & & & & \\
& & 0.60 & 1.05 & 1.05 & 1.05 & 1.05 \\
$\begin{array}{l}\text { Trichloroacetic } \\
\text { acid }+2.85 \mathrm{mg} / 1 \mathrm{P}_{\mathrm{i}}\end{array}$ & & & & & & \\
+ serum & & & & & & \\
\hline
\end{tabular}

Data represented as $\mathbf{A}_{640} \mathrm{~nm}$.

Serum blanik wạs subtracted.

\section{Effect of the type of reducing agent}

As shown in figure 1, both stannous chloride and ascorbic acid could be used as reducing agents in a concentration of 114-285 mg/l. Stannous chloride at a final concentration of $214 \mathrm{mg} / \mathrm{l}$ was used for colour development through out the present study. However, 




Fig. 1. Effect of type and concentrations of reducing agent.

Stannous chloride.

- Formic acid-glycerol method

$\Delta$ Trichloroacetic acid method

Ascorbic acid.

o Formic acid-glycerol method

$\Delta$ Trichloroacetic acid method

the absorbance values obtained with stannous chloride were approximately three times those obtained when ascorbic acid was used.

\section{Effect of serum concentration on phosphorus determination}

Determination of phosphorus in the presence of up to $0.2 \mathrm{ml}$ serum (double the volume required for the assay), did not interfere with intensity and stability of colour development. Jaundiced specimens did not represent any problem since the yellow colour due to bilirubin did not absorb at $640 \mathrm{~nm}$.

\section{Characteristics of the colour reaction \\ Rate and stability of colour reaction}

When phosphorus was determined as outlined in Table 1 in the presence or absence of serum, the optimal colour was developed after 30 and 20 minutes at $20^{\circ} \mathrm{C}$ and $37^{\circ} \mathrm{C}$ respectively. The colour was found to be stable for a period of up to six hours.

\section{Maximal absorbance of the colour}

The colour of the reduced phosphomolybdate, developed under the described conditions, absorbs maximally in the range of 640-720 nm irrespective of the reducing agent used.

\section{Sensitivity of formic acid-glycerol method}

To test the validity and accuracy of the formic acidglycerol method, phosphoris determinations were carried out over a wide range of concentrations. The results were compared with those obtained after removal

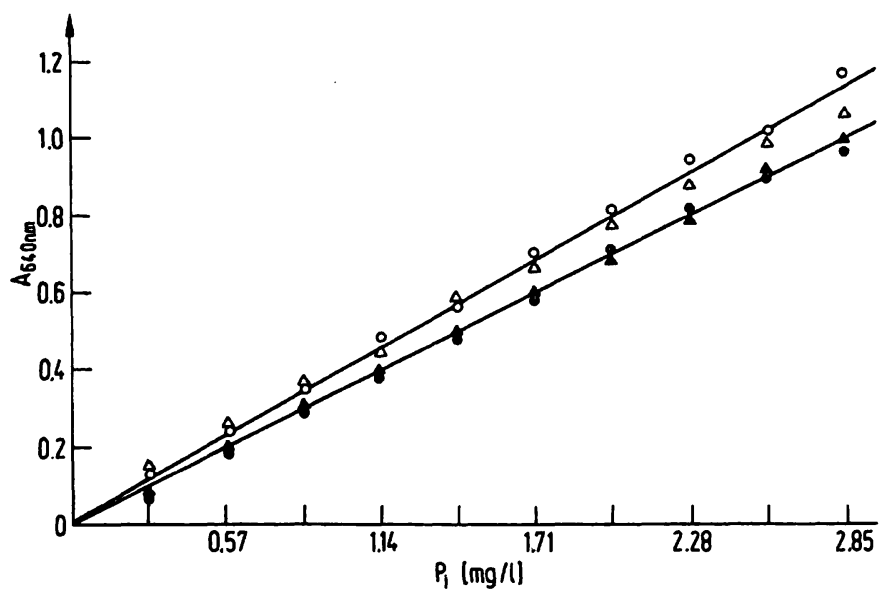

Fig. 2. Standard phosphorus-curve.

Formic acid-glycerol method.

- in presence of serum

$\Delta$ in absence of serum

Trichloroacetic acid method.

$\circ$ in presence of serum

$\Delta$ in absence of serum

of protein by trichloroacetic acid. As shown in figure 2 linearity could be obtained up to $2.85 \mathrm{mg} / \mathrm{l}$ phosphorus. When a concentration of 0.285 to $2.85 \mathrm{mg} / \mathrm{l}$ phosphorus was added to serum, the percentage recovery was found to be $100 \pm 5$ with the formic acid-glycerol method, compared with $98.6 \pm 5.4$ after deproteinization with trichloroacetic acid.

\section{Specificity of formic acid-glycerol method for inorganic phosphorus}

The specificity of the reaction for inorganic phosphorus was checked using various organic phosphates. With $5 \mathrm{mmol} / \mathrm{l}$ adenosine-5'-mono- and tri-phosphate, glucose-6-phosphate, $\beta$-glycerophosphate and $p$-nitrophenyl phosphate, absorbance values in the range of zero to 0.15 were obtained, whereas $32 \mu \mathrm{mol} / \mathrm{l}$ inorganic phosphate gave absorbance values in the order of unity (see tab. 4).

Tab. 4. Specificity of formic acid-glycerol method for inorganic phosphorus.

\begin{tabular}{lllll}
\hline Method & \multicolumn{2}{l}{$\begin{array}{l}\text { Trichloroacetic } \\
\text { acid }\end{array}$} & \multicolumn{3}{l}{$\begin{array}{l}\text { Formic acid- } \\
\text { glycerol }\end{array}$} \\
\hline Substrate & $1 \mathrm{~h}$ & $3 \mathrm{~h}$ & $1 \mathrm{~h}$ & $3 \mathrm{~h}$ \\
& & & & \\
5'-AMP (5 mmol/1) & 0.00 & 0.00 & 0.02 & 0.02 \\
$\begin{array}{l}\text { Glucose-6-phosphate } \\
\text { (5 mmol/1) }\end{array}$ & 0.00 & 0.00 & 0.01 & 0.01 \\
$\begin{array}{l}\text { p-Nitrophenyl } \\
\text { phosphate (5 mmol/1) }\end{array}$ & 0.11 & 0.11 & 0.01 & 0.11 \\
$\begin{array}{l}\text { ATP (5 mmol/1) } \\
\beta \text {-Glycerophosphate } \\
\text { (5 mmol/1) }\end{array}$ & 0.09 & 0.11 & 0.11 & 0.12 \\
\begin{tabular}{l} 
P (32 $\mu$ mol/l) \\
\hline
\end{tabular} & 1.05 & 0.00 & 0.01 & 0.02 \\
\hline
\end{tabular}

Data represented as $\mathbf{A}_{640} \mathrm{~nm}$ 
Clinical application of formic acid-glycerol method for serum phosphorus determination

The level of phosphorus in the serum of normal Egyptian subjects (100 cases) determined by the formic acidglycerol method outlined in Table 1 was found to be $4.3 \pm 0.7$ (range $3-6$ ) $\mathrm{mg} / \mathrm{dl}$ serum. This correlates well with the values obtained after deproteinization with trichloroacetic acid which were $4.8 \pm 0.8 \mathrm{mg} / \mathrm{dl}$ serum.

\section{Discussion}

Development of a simple method for the determination of serum inorganic phosphorus without deproteinization is of great importance in routine analysis of phosphorus and phosphatase in serum. The deproteinization step represents the main difficulty in full mechanisation.

Different methods have been previously reported that deal with phosphorus determination in serum without deproteinization. Some are based on colorimetric measurement of the phospho-molybdate complex, either in its reduced form in alkaline medium (4), or its unreduced form in acid medium (5). Another depends on spectrometric measurements (6).

However, colorimetric determination of the reduced phosphomolybdate complex in acid medium without removal of serum protein has not hitherto been reported. This has been achieved in the present work, using formic acid and glycerol.

Neither formic acid nor glycerol was enough to keep serum protein in solution after the addition of molybdate ions. Formic acid in a concentration of $348 \mathrm{~g} / \mathrm{l}$ and glycerol in a concentration of $107 \mathrm{~g} / 1$ was found to be convenient for colour development with phosphate. Glycerol at a higher concentration (145 g/l) abolished the colour development. However, this effect on colour development could be prevented if serum was added, or its concentration was reduced to $107-125 \mathrm{~g} / 1$.

The mechanism involved in solubilization of serum protein by the combined action of formic acid and glycerol may involve two steps. The first step is solubilization of protein by formic acid, which also acidifies the medium, a step necessary for colour development. The second step is stäbilization of the system through the chelation of molybdenum with the hydroxyl group of glycerol, thus preventing protein precipitation without interfering with the formation of phosphate-molybdate complex. This speculation was supported by the data presented in Table 3 .

With stannous chloride as the reducing agent, the sensitivity of the method was three times higher than with ascorbic acid. Stannous chloride does not interfere with the stability of the system, or with colour development.

The present method proved specific for inorganic phosphorus. The fact that organic monophosphate esters are not affected by formic acid made it possible to use this method for the determination of serum phosphatases without deproteinization (this will be reported in a separate publication). The levels of phosphorus in the serum of normal Egyptian subjects determined by this method correlate well with the values obtained after deproteinization with trichloroacetic acid reported here and in the literature $(1,7-9)$.

The stability of the colour and the ease of measuring the blue colour give the method great advantages over the trichloroacetic acid method. By avoiding precipitation it is possible to fully mechanize the phosphorus determination.

\section{References}

1. Fiske, C. H. \& Subbarow, Y. (1925), J. Biol. Chem. 66, 375-400.

2. Heppel, L. A. \& Hilmoe, R. J. (1951), J. Biol. Chem. 235, 471-474.

3. Kuttner, T. \& Lichtenstein, L. (1930), J. Biol. Chem. 86, 671-675.

4. Raabe, S. (1955), Rec. Trav. Chim., 74, 651-660

5. Daly, J. A. \& Ertingshansen, G. (1972), Clin. Chem. 18, 263-265.
6. Baginski, E. S., Marie, S. S. \& Zak, B. (1974), Microchem. J., 19, 285-294.

7. Birggs, A. P. (1920), J. Biol. Chem. 53, 13-18.

8. King, E. J. \& Wootton, I. D. P. (1956), Microanalysis in biochemistry 3 rd ed. J. \& Churchill, p. 76.

9. Guirgis, F. K. \& Habib, Y. A. (1971), Clin. Chem. 17, 78-81.

Dr. M. M. Ël-Merzabani Cancer Chemotherapy Unit Cancer Institute Cairo, Ėgypt. 